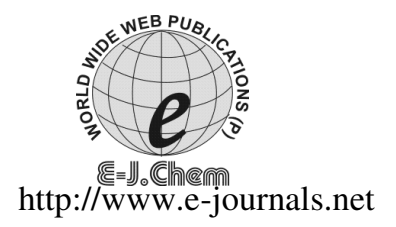

ISSN: 0973-4945; CODEN ECJHAO

E-Journal of Chemistry 2010, 7(1), 287-294

\title{
Ion Exchange Properties of Resins Derived from $p$-Hydroxybenzaldehyde, Resorcinol and Formaldehyde
}

\author{
V. V. HIWASE*, A. B. KALAMBE, K. M. KHEDKAR and S. D. DEOSARKAR ${ }^{\S}$
}

*Arts, Commerce \& Science College, Arvi, Dist- Wardha, India.

Institute of Science, Nagpur, India.

${ }^{\S}$ S.F.S. College, Nagpur, India.

vvhiwase72@rediffmail.com

Received 17 January 2009; Revised 1 July 2009; Accepted 1 September 2009

\begin{abstract}
The terpolymeric resins were prepared by base catalyzed polycondensation of $p$-hydroxybenzaldehyde, resorcinol and formaldehyde. Resin obtained by molar monomer composition, $p$-hydroxybenzaldehyde: resorcinol: formaldehyde as 1:1:3 was abbreviated as PHBRF-I and that prepared by 1:2:4 composition was abbreviated as PHBRF-II. These resins were characterized by physicochemical methods such as elemental analysis, UV-Vis, IR and NMR. ionexchange study was carried out with $\mathrm{Cu}^{2+}, \mathrm{Zn}^{2+}, \mathrm{Ni}^{2+}, \mathrm{Co}^{2+}, \mathrm{Pb}^{2+} \& \mathrm{Cd}^{2+}$ by batch equilibrium method. The rate of metal ion uptake by PHBRF-II terpolymeric resin was higher than that of PHBRF-I. Effect of $\mathrm{pH}$ and electrolytes under specified condition were also studied. The terpolymeric resins show high selectivity for $\mathrm{Cu}^{2+}, \mathrm{Zn}^{2+}$ and $\mathrm{Co}^{2+}$ as compared to $\mathrm{Ni}^{2+}, \mathrm{Pb}^{2+}$ and $\mathrm{Cd}^{2+}$.
\end{abstract}

Keywords: Terpolymeric resin, Batch equilibrium method, Effect of electrolyte.

\section{Introduction}

Polymeric chelating ion exchange materials open a wide hope of opportunities in industrial, environmental and biological application owing to their metal ion-exchange selectivity and low cost of production and easy regeneration ${ }^{1,2}$. Incorporation functional group into the polymeric matrix is of great interest in connection with trace concentration of heavy metal ions. Various phenolics formaldehyde co-polymers have been reported to have satisfactory ion exchange properties ${ }^{3,4}$. Recently, Pal et $a l^{5,6}$ reported the ion exchange properties of salicylic acid, dithiobiuret / dithioxamide trioxane tercopolymers and reported selectivity metal ion uptake over wide range of $\mathrm{pH}$ and found that resin show high selectivity for fast 
and low for $\mathrm{Pb}^{2+}$ and $\mathrm{Hg}^{2+}$. Many workers ${ }^{7}$ synthesized polystyrene based chelating with 1-nitroso-2-napthol as functional group and studied the chelating ion exchange properties. Chelation ion exchange resin obtained by polycondensation of salicylaldehyde, biuret and trioxane has been reported ${ }^{8}$. Manavalan et $a l^{9}$ synthesized $p$-hydroxybenzoic acid-thioureaformaldehyde resin and studied ion exchange properties. Banerjee et al ${ }^{10}$ functionalized amberlite IRC-50 resin by 8 -aminoquinoline group. The resin was found to be very useful for preconcentration and separation of copper and zinc. Shah et al ${ }^{11,12}$ reported the ion exchange properties of anthranilic acid-resorcinol-formaldehyde and 8-hydroxyquinolinecatechol-fomaldehyde terpolymeric resins. The synthesis and ion exchange properties of resin derived from $p$-hydroxyacetophenone; hexamine and formaldehyde were previously reported ${ }^{13}$. The present paper deals with synthesis and comparative ion exchange study of newly synthesized resin obtained by base catalyzed polycondensation of p-hydroxybenzaldehyde, resorcinol and formaldehyde (PHBRF-I \& PHBRF-II). The tentative structures terpolymeric resins are given below.

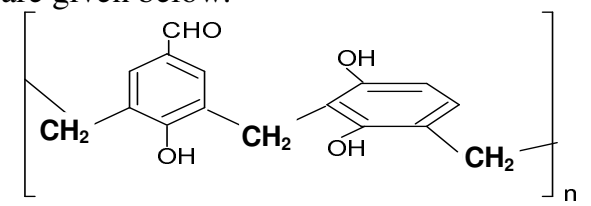<smiles>CC(C)Cc1cc(C=O)cc(Cc2c(O)ccc(Cc3ccc(O)c(CC(C)C)c3O)c2O)c1O</smiles>

\section{Experimental}

All chemicals used were of A.R. or Chemically pure grade.

\section{Synthesis of resins}

PHBRF-I was prepared by condensing $p$-hydroxybenzaldehyde $(0.1 \mathrm{M})$, resorcinol $(0.1 \mathrm{M})$ and formaldehyde $(0.3 \mathrm{M})$ was refluxed in presence of $1 \mathrm{M} \mathrm{NaOH}(100 \mathrm{~mL})$ in an oil bath at $122-125{ }^{\circ} \mathrm{C}$ for $6.0 \mathrm{~h}$. Similarly PHBRF-II was prepared by using $p$-hydroxy-benzaldehyde $(0.1 \mathrm{M})$, resorcinol $(0.2 \mathrm{M})$ and formaldehyde $(0.4 \mathrm{M})$. Buff red colored products were precipitated by treating it with $1: 1 \mathrm{HCl}$. The products were washed several times with hot water to remove unreacted reactants and finally squeezed with ether to remove if any $p$ hydroxybenzaldehyde-formaldehyde co-polymer which might be formed along with PHBRF tercopolymer. The products were further purified by dissolving in $10 \% \mathrm{NaOH}$ and reprecipitated with 1:1 $\mathrm{HCl}$. Finally the products were washed several times with hot water (deionised, $0.3 \mu \mathrm{S} \mathrm{cm}^{-1}$ conductivity). PHBRF-I and PHBRF-II were found to be $78 \%$ \& $72 \%$. The products were dried in vacuum desiccator. The dried products were grinded and sieved in 300 mesh sieve. The synthetic details are summarized in Table 1

Table 1. Synthetic details.

\begin{tabular}{cccccccc}
\hline Resins & $\begin{array}{c}p \text {-Hydroxy- } \\
\text { acetophenone }\end{array}$ & Hexamine & $\begin{array}{c}\text { Formal } \\
\text { dehyde }\end{array}$ & $\begin{array}{c}\text { Catalyst } \\
0.2 \mathrm{M} \mathrm{HCl}\end{array}$ & $\begin{array}{c}\text { React. } \\
\text { Temp. }{ }^{\circ} \mathrm{C}\end{array}$ & $\begin{array}{c}\text { Time, } \\
\text { h }\end{array}$ & Yield, \% \\
\hline PHBRF-I & $0.1 \mathrm{M}$ & $0.1 \mathrm{M}$ & $0.3 \mathrm{M}$ & $100 \mathrm{~mL}$ & $120 \pm \square 2$ & 6.00 & 78 \\
PHBRF-II & $0.1 \mathrm{M}$ & $0.2 \mathrm{M}$ & $0.4 \mathrm{M}$ & $100 \mathrm{~mL}$ & $120 \pm \square 3$ & 5.00 & 72 \\
\hline
\end{tabular}




\section{Procedure for determination of the effect of electrolyte on metal uptake}

The resin sample $(25 \mathrm{mg}$ ) was suspended in electrolyte solution of required concentration $\left(25 \mathrm{~mL}\right.$ ) for $24 \mathrm{~h}$. The $\mathrm{pH}$ of solution was to 6.0 using $0.1 \mathrm{M} \mathrm{HNO}_{3}$ or $0.1 \mathrm{M} \mathrm{NaOH}$. To this solution $2 \mathrm{~mL}$ of $0.1 \mathrm{M}$ metal nitrate solution added at room temperature and $\mathrm{pH}$ was adjusted to required value. The mixture was stirred again at room temperature for $24 \mathrm{~h}$ and filtered. Solids were washed and washings were quantitatively combined with filtrate. The metal content was determined by direct EDTA titration. The amount of metal exchanged was determined from the difference between blank and reading in actual experiment. The amounts of metal ion in mg per $\mathrm{g}$ of resin were calculated in presence of $\mathrm{NaNO}_{3}, \mathrm{NaCl}$, and $\mathrm{Na}_{2} \mathrm{SO}_{3}$ and $\mathrm{Na}_{2} \mathrm{SO}_{4}$ electrolyte for metal ions $\mathrm{Cu}^{2+}, \mathrm{Zn}^{2+}, \mathrm{Ni}^{2}+, \mathrm{Co}^{2+}, \mathrm{Pb}^{2+}$ and $\mathrm{Cd}^{2+}$.

Procedure for evaluation of rate of metal ion uptake

In order to determine optimum time required to reach the equilibrium the experiments were performed as above but here metal ion uptake was estimated as a function of time in $\mathrm{h}$ in presence of $1 \mathrm{M} \mathrm{NaNO}_{3}$ solution $(25 \mathrm{~mL})$. It was assumed that the equilibrium state was established within $24 \mathrm{~h}$. The rate of metal uptake was expressed in percent uptake related to state of equilibrium.

$$
\% \text { Metal uptake }=\begin{aligned}
& \text { mg of metal sorbed in given time } \\
& \text { mg of metal sorbed in } 24 \mathrm{~h}
\end{aligned} \quad \times 100
$$

\section{Procedure to study effect of $\mathrm{pH}$ on metal uptake}

The resin sample $25 \mathrm{mg}$ was allowed to swell for $24 \mathrm{~h}$ in $1 \mathrm{M} \mathrm{NaNO}_{3}$ solution. The $\mathrm{pH}$ was adjusted to required value as above. $2 \mathrm{~mL}$ of $0.1 \mathrm{M}$ metal nitrate solution was added. The $\mathrm{pH}$ was maintained again and stirred for $24 \mathrm{~h}$. Metal was estimated by EDTA titration to determine the distribution $\mathrm{K}_{\mathrm{D}}$ value between polymer phase and solution phase. The $\mathrm{K}_{\mathrm{D}}$ value was calculated by formula,

$$
\begin{aligned}
& \mathrm{K}_{\mathrm{D}} \quad \mathrm{mg} \text { of metal exchanged per gm of resin } \\
& \mathrm{mg} \text { of metal present in } 1 \mathrm{~mL} \text { of solution }
\end{aligned}
$$

\section{Results and Discussion}

The elemental analysis of PHBRF resins was carried out in SAIF, Chandigarh the data are represented in Table 2.

Table 2. Elemental analysis of PHBRF resin.

\begin{tabular}{cccccccc}
\hline \multirow{2}{*}{ Resin } & \multicolumn{2}{c}{$\% \mathrm{C}$} & \multicolumn{2}{c}{$\% \mathrm{H}$} & \multicolumn{2}{c}{$\% \mathrm{O}$} & \multirow{2}{*}{$\begin{array}{c}\text { Molecular formula } \\
\text { of repeat unit }\end{array}$} \\
\cline { 2 - 7 } & Calc & Found & Calc. & Found & Calc. & Found & \\
\hline PHBRF- I & 71.11 & 70.77 & 5.18 & 5.30 & 23.71 & 23.38 & $\mathrm{C}_{16} \mathrm{H}_{14} \mathrm{O}_{4}$ \\
PHBRF-II & 70.41 & 69.84 & 5.10 & 5.13 & 24.49 & 24.26 & $\mathrm{C}_{23} \mathrm{H}_{20} \mathrm{O}_{6}$ \\
\hline
\end{tabular}

\section{Electronic absorption spectra of PHBRF- resin}

Electronic spectra of all PHBRF resin samples were recorded in DMF solvent in region 250-750 $\mathrm{nm}$. The spectra are shown in Figure 1. It can be seen from the spectra that, the absorption bands do not show shifting pronouncedly toward either shorter or longer wavelength with increase in the composition of either $p$-hydroxybenzaldehyde or resorcinol relative to each other. Moreover the absorption spectra of PHBRF-II show hyperchromic effect with increase in number of -OH group in repeating unit of PHBRF-II resins as compared to PHBRF-I at higher $\lambda \square$. These absorptions clearly indicate the presence of carbonyl group. The mentioned absorption are attributed to $n-\pi^{*}$ transition. In addition to these, bands due to $\pi-\pi^{*}$ transition are also observed toward shorter wave length. The observations of spectra are summarized in Table 3 


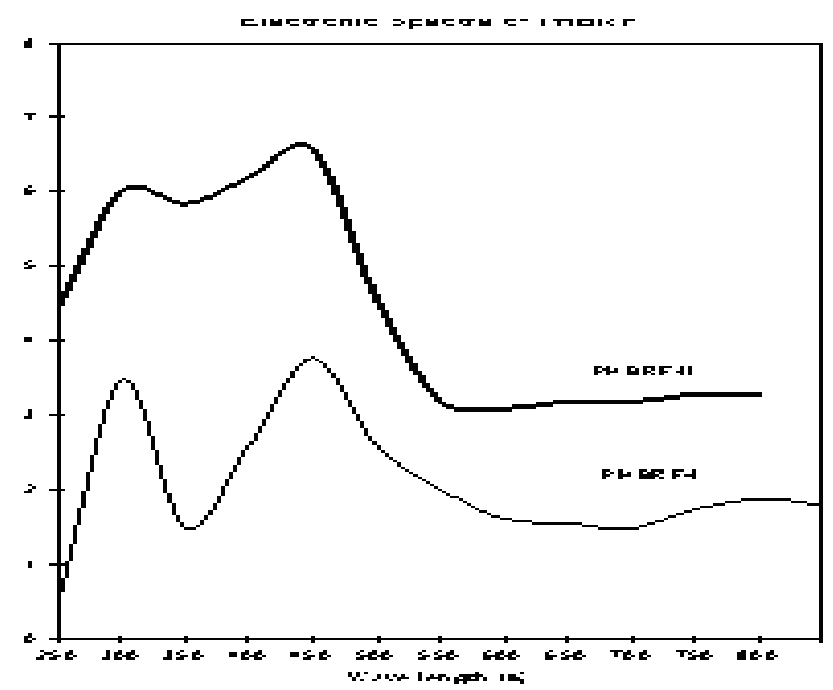

Figure 1. Electronic Spectra of PHBRF resins.

Table 3. Characteristic absorption bands and related transitions.

\begin{tabular}{cccc}
\hline Resin & $\begin{array}{c}\text { Wavelength, nm } \\
\text { range for } \mathrm{n}-\pi^{*} \text { transition }\end{array}$ & $\begin{array}{c}\text { Wavelength, nm } \\
\text { range for } \pi-\pi^{*} \text { transition }\end{array}$ & Group \\
\hline PHBRF-I & 450 & 300 & $>\mathrm{C}=\mathrm{O}$ \\
PHBRF-II & 450 & 320 & $>\mathrm{C}=\mathrm{O}$ \\
\hline
\end{tabular}

\section{Infrared spectra}

Infra red spectra of all PHBRF terpolymeric resins are shown in Figure 2 and characteristics IR data are listed in Table 4. It can be seen from spectra of PHBRF resins that show nearly same IR spectra. The broad band at $3200-3450 \mathrm{~cm}^{-1}$ was assigned to $\mathrm{H}$-bonded $-\mathrm{OH}$ group. The characteristic two bands at 2940 and $2840 \mathrm{~cm}^{-1}$ was assigned to $-\mathrm{CH}$ stretch in -CHO group. Bands at 1600, 1500 and around $1440-1460 \mathrm{~cm}^{-1}$ was due to aromatic rings. The strong band at $1680 \mathrm{~cm}^{-1}$ clearly indicate presence of carbonyl group $(>\mathrm{C}=\mathrm{O})$ in aldehydes. The medium band at $1380 \mathrm{~cm}^{-1}$ assigned to $-\mathrm{CH}_{2}$ - bridges linking two resorcinol moieties. This band is absent in IR spectra of PHBRF-I clearly support the assigned structure of PHBRF-I resin shown above. The characteristics band at $1280 \mathrm{~cm}^{-1}$ was assigned to $-\mathrm{CH}_{2^{-}}$bridges between $p$ hydroxybenzaldehyde and resorcinol moieties. The characteristics medium bands around 1220 and $1080 \mathrm{~cm}^{-1}$ indicate the presence of 1,2,3,5-tetrasubstituted aromatic rings. Moreover the bands at $840 \mathrm{~cm}^{-1}$ were assigned to 1, 2, 3, 4- tetra substituted aromatic rings.

Table 4. Characteristic IR data of PHBRF resin ${ }^{14-16}$.

\begin{tabular}{ccl}
\hline PHBRF -I, cm & PHBRF- II, $\mathrm{cm}^{-1}$ & \multicolumn{1}{c}{ Assignments } \\
\hline $3200-3450(\mathrm{~b})$ & $3200-3450(\mathrm{~b})$ & H-bonded -OH (Phenolic) \\
$2940,2840(\mathrm{w})$ & $2940,2840(\mathrm{w})$ & $-\mathrm{CHO}$ \\
$1680(\mathrm{~s})$ & $1680(\mathrm{~s})$ & $-\mathrm{C}=\mathrm{O}$ str. (aldehydes) \\
$1500,16001440(\mathrm{~m})$ & $1508,16001440(\mathrm{~m})$ & Aromatic ring \\
----- & $1380(\mathrm{~m})$ & Res- $\mathrm{CH}_{2}-$ Res moiety, (Res = Resorcinol) \\
$1280(\mathrm{~m})$ & $1280(\mathrm{~m})$ & PHB-CH - Res moiety, \\
$1180,1100(\mathrm{~m})$ & $1220,1080(\mathrm{~m})$ & (PHB $=$ p-Hydroxybenzaldehyde) \\
$840(\mathrm{w})$ & $840(\mathrm{w})$ & $1,2,3,5-$ Tetra substituted benzene ring \\
\end{tabular}




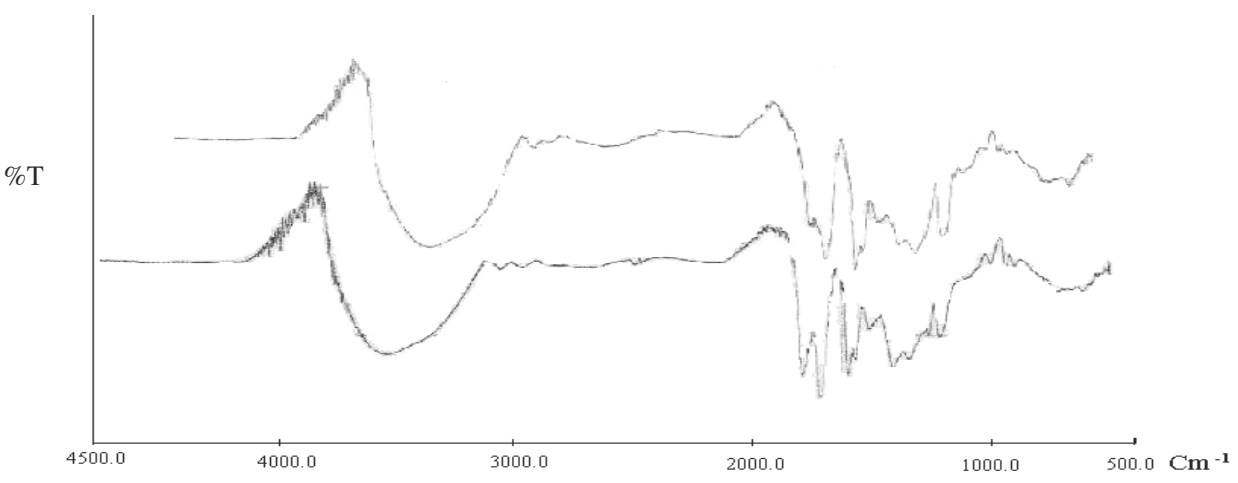

Figure 2. IR spectra of PHBRF resins.

\section{Ion exchange properties}

The data from the Table 5 reveals that rate of metal ion uptake of PHBRF- I is higher for $\mathrm{Cu}^{2+}$ and lowest for $\mathrm{Pb}^{2+}$. Rate of metal ion uptake show the order $\mathrm{Cu}^{2+}>\mathrm{Co}^{2+}>\mathrm{Zn}^{2+}$ $>\mathrm{Cd}^{2+}>\mathrm{Pb}^{2+}>\mathrm{Ni}^{2+}$. PHBRF-II is more selective for $\mathrm{Zn}^{2+}$. PHBRF-II has comparatively higher exchange rate than PHBRF-I. The lower rate of $\mathrm{Cd}^{2+}$ and $\mathrm{Pb}^{2+}$ may be due to comparatively larger size of the ions and steric effect. Effect of electrolyte on ion exchange is summarized in Table 6. The inspection of data reveals that the amount of metal uptake in presence of $\mathrm{NaNO}_{3}$ is larger than $\mathrm{NaCl}, \mathrm{Na}_{2} \mathrm{SO}_{4}$ and $\mathrm{Na}_{2} \mathrm{SO}_{3}$. It is interesting to note that resin PHBRF do not exchange $\mathrm{Pb}^{2+}$ and $\mathrm{Cd}^{2+}$ in presence of $\mathrm{Na}_{2} \mathrm{SO}_{3}$ and $\mathrm{Na}_{2} \mathrm{SO}_{4}$. For the metal ions such as $\mathrm{Cu}^{2+}, \mathrm{Zn}^{2+}, \mathrm{Ni}^{2+}$, and the exchange capacity increases with increase in the concentration of $\mathrm{NO}_{3}{ }^{-}$and $\mathrm{Cl}^{-}$. Whereas it decreases with increase in concentration of $\mathrm{SO}_{3}{ }^{2-}$ and $\mathrm{SO}_{4}{ }^{2-}$. The effect of $\mathrm{pH}$ on distribution ratios of metal ion between resin and solution phase can be explained by revealing the data given in Table 7 . The study was carried out in the limit of higher $\mathrm{pH}$ in order to prevent hydrolysis of metal ions. $\mathrm{K}_{\mathrm{D}}$ values in general found to follow the order PHBRF-II $>$ PHBRF-I. $\mathrm{K}_{\mathrm{D}}$ values of metal ions were found to increase with increase in $\mathrm{pH}$. The lower distribution ratios of $\mathrm{Pb}^{2+}$ may be attributed to steric effect and low stability constant i.e. weak ligand stabilization energy of metal complexes.

The possible order of ion exchange for divalent ions is $\mathrm{Pb}>\mathrm{Cu}>\mathrm{Ni}>\mathrm{Co}>\mathrm{Zn}>\mathrm{Cd}>$ $\mathrm{Fe}>\mathrm{Mn} .>\mathrm{Mg}$. In present study, PHBRF- I and PHBRF-II show the order of $\mathrm{K}_{\mathrm{D}}$ values $\mathrm{Pb}^{2+}$ $<\mathrm{Cd}^{2+}<\mathrm{Ni}^{2+}<\mathrm{Co}^{2+}<\mathrm{Cu}^{2+}<\mathrm{Zn}^{2+}$ and $\mathrm{Cd}^{2+}<\mathrm{Cu}^{2+}<\mathrm{Pb}^{2+}<\mathrm{Ni}^{2+}<\mathrm{Zn}^{2+}<\mathrm{Co}^{2+}$ respectively at pH 6.0. At pH 3.0, PHBRF-I show the order $\mathrm{Co}^{2+}<\mathrm{Pb}^{2+}<\mathrm{Ni}^{2+}<\mathrm{Cu}^{2+}<\mathrm{Zn}^{2+}$ and for PHBRF- II the order of $\mathrm{K}_{\mathrm{D}}$ values is $\mathrm{Cd}^{2+}<\mathrm{Pb}^{2+}<\mathrm{Ni}^{2+}<\mathrm{Cu}^{2+}<\mathrm{Zn}^{2+}<\mathrm{Co}^{2+}$. The result of the study obviously is helpful in the separation of metal ions. For example the separation of $\mathrm{Co}^{2+}$ and $\mathrm{Zn}^{2+}$ can be achieved using PHBRF-I at optimum $\mathrm{pH}$ 3.0. Similarly for efficient separation of $\mathrm{Zn}^{2+}$ and $\mathrm{Pb}^{2+}$ the optimum $\mathrm{pH}$ is 6.0.

Table 5. Percent rate of metal ion uptake.

\begin{tabular}{cccccccc}
\hline $\mathrm{M}^{2+}$ & Time, $\mathrm{H}$ & PHBRF-I & PHBRF-II & $\mathrm{M}^{2+}$ & Time, $\mathrm{h}$ & PHBRF-I & PHBRF-II \\
\hline & 1 & 42.34 & 53.17 & $\mathrm{Cd}^{2+}$ & 1 & 48.26 & 54.37 \\
& 2 & 54.62 & 68.46 & & 2 & 55.25 & 59.37 \\
$\mathrm{Cu}^{2+}$ & 3 & 68.25 & 74.36 & & 3 & 61.18 & 68.11 \\
& 4 & 74.39 & 85.32 & & 4 & 72.38 & 78.29 \\
& 5 & 88.73 & 92.35 & & 5 & 79.55 & 82.93 \\
& 6 & 96.33 & 98.05 & & 6 & 82.34 & 88.25 \\
& 7 & $\sim$ & $\sim$ & & 7 & 87.06 & 93.45 \\
\hline
\end{tabular}




\begin{tabular}{cccccccc}
\hline & 1 & 19.29 & 24.18 & $\mathrm{Ni}^{2+}$ & 1 & 29.53 & 48.11 \\
& 2 & 54.76 & 59.91 & & 2 & 59.46 & 75.43 \\
$\mathrm{Zn}^{2+}$ & 3 & 69.04 & 70.46 & & 3 & 68.47 & 81.34 \\
& 4 & 70.56 & 78.73 & & 4 & 77.16 & 86.41 \\
& 5 & 74.57 & 84.64 & & 5 & 85.24 & 90.47 \\
& 6 & 84.21 & 91.56 & & 6 & 91.28 & 96.35 \\
& 7 & $\sim$ & $\sim$ & & 7 & $\sim$ & $\sim$ \\
\hline & 1 & 42.18 & 48.41 & $\mathrm{Co}^{2+}$ & 1 & 35.63 & 47.5 \\
$\mathrm{~Pb}^{2+}$ & 2 & 57.44 & 64.23 & & 2 & 48.17 & 53.21 \\
& 3 & 65.34 & 75.43 & & 3 & 62.33 & 68.33 \\
& 4 & 71.15 & 81.35 & & 4 & 78.24 & 82.46 \\
& 5 & 79.35 & 84.44 & & 5 & 85.46 & 88.17 \\
& 6 & 81.11 & 85.29 & & 6 & 90.72 & 94.67 \\
\hline
\end{tabular}

$\mathrm{Mt}\left(\mathrm{NO}_{3}\right)=0.1 \mathrm{M}, 2 \mathrm{~mL}$, Electrolyte $=\mathrm{NaNO}_{3} 1 \mathrm{M} 25 \mathrm{~mL}$, Equilibrium state $=24 \mathrm{~h}$, Wt. of resin $=25 \mathrm{mg}$, Temp. $=$ Room Temp, Error $= \pm 5 \%$.

Table 6. Amount of metal ion exchanged (mg) per gram of resin.

\begin{tabular}{|c|c|c|c|c|c|c|c|c|c|}
\hline \multirow[b]{2}{*}{ 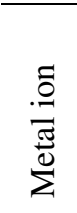 } & \multirow[b]{2}{*}{ 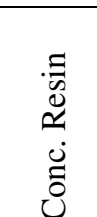 } & \multicolumn{2}{|c|}{$\mathrm{NaNO}_{3}$} & \multicolumn{2}{|c|}{$\mathrm{NaCl}$} & \multicolumn{2}{|c|}{$\mathrm{Na}_{2} \mathrm{SO}_{3}$} & \multicolumn{2}{|c|}{$\mathrm{Na}_{2} \mathrm{SO}_{4}$} \\
\hline & & $\begin{array}{l}\frac{1}{\frac{1}{\alpha}} \\
\frac{a}{n} \\
\frac{1}{2}\end{array}$ & 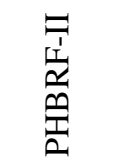 & $\begin{array}{l}\frac{r}{\frac{1}{\alpha}} \\
\frac{a}{n} \\
\frac{1}{a}\end{array}$ & 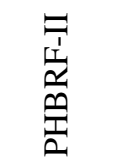 & 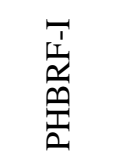 & 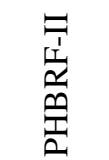 & $\begin{array}{l}\overrightarrow{1} \\
\underline{a} \\
\underline{a} \\
\underline{a} \\
\underline{a}\end{array}$ & 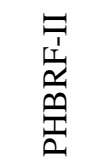 \\
\hline & 0.0125 & 52.37 & 86.34 & 45.21 & 78.15 & 82.64 & 104.79 & 90.76 & 94.43 \\
\hline & 0.025 & 113.55 & 104.35 & 98.46 & 125.48 & 69.44 & 80.12 & 74.33 & 84.26 \\
\hline & 0.5 & 142.38 & 165.75 & 114.35 & 136.11 & 42.58 & 67.26 & 64.54 & 79.77 \\
\hline & 1 & 154.32 & 178.25 & 134.26 & 174.34 & 34.26 & 47.35 & 58.43 & 68.14 \\
\hline & 0.0125 & 84.25 & 113.4 & 63.47 & 88.76 & 105.94 & 112.85 & 115.36 & 128.34 \\
\hline & 0.025 & 117.65 & 174.88 & 98.41 & 144.38 & 87.42 & 90.06 & 78.14 & 90.42 \\
\hline & 0.5 & 124.43 & 193.4 & 133.22 & 175.37 & 59.45 & 68.32 & 68.36 & 74.55 \\
\hline & 1 & 181.22 & 224.27 & 174.41 & 206.47 & 38.41 & 33.14 & 53.24 & 68.96 \\
\hline & 0.0125 & 66.28 & 94.63 & 55.73 & 83.14 & NOE & NOE & NOE & NOE \\
\hline & 0.025 & 122.04 & 286.34 & 94.89 & 123.84 & NOE & NOE & $\mathrm{NOE}$ & NOE \\
\hline & 0.5 & 203.47 & 412.87 & 128.33 & 145.53 & NOE & NOE & NOE & NOE \\
\hline & 1 & 322.48 & 589.33 & 152.74 & 189.25 & NOE & NOE & NOE & NOE \\
\hline & 0.0125 & 54.98 & 87.26 & 46.25 & 59.15 & 98.152 & 129.24 & 80.74 & 105.4 \\
\hline & 0.025 & 75.65 & 124.75 & 61.854 & 78.69 & 84.36 & 97.23 & 76.12 & 94.25 \\
\hline & 0.5 & 96.34 & 165.37 & 85.31 & 94.63 & 56.47 & 78.14 & 53.67 & 81.37 \\
\hline & 1 & 127.3 & 180.24 & 115.47 & 124.3 & 36.44 & 55.25 & 34.75 & 59.46 \\
\hline & 0.0125 & 64.25 & 94.65 & 52.34 & 84.22 & 74.12 & 98.27 & 85.14 & 115.24 \\
\hline & 0.025 & 85.74 & 145.85 & 66.48 & 124.88 & 55.26 & 67.14 & 60.54 & 91.24 \\
\hline & 0.5 & 117.35 & 184.23 & 87.41 & 153.47 & 34.22 & 55.42 & 49.13 & 75.63 \\
\hline & 1 & 134.52 & 207.14 & 116.14 & 174.32 & 27.52 & 42.11 & 34.15 & 55.24 \\
\hline & 0.0125 & 124.89 & 142.47 & 68.43 & 114.75 & NOE & $\mathrm{NOE}$ & $\mathrm{NOE}$ & $\mathrm{NOE}$ \\
\hline & 0.025 & 165.47 & 178.25 & 123.62 & 173.12 & NOE & NOE & NOE & NOE \\
\hline & 0.5 & 204.74 & 215.45 & 147.22 & 204.42 & NOE & NOE & NOE & NOE \\
\hline & 1 & 225.15 & 239.35 & 174.54 & 244.18 & NOE & NOE & NOE & NOE \\
\hline
\end{tabular}

$\mathrm{Mt}\left(\mathrm{NO}_{3}\right)=0.1 \mathrm{M}, 2 \mathrm{~mL}$, Electrolyte $=1 \mathrm{M} 25 \mathrm{~mL}$, Equilibrium state $=24 \mathrm{~h}$, Wt. of resin $=25 \mathrm{mg}$.

Temp $=$ Room temp. NOE $=$ No exchange. 
Table 7. Distribution $\mathrm{K}_{\mathrm{D}}$ values of different metal ions as a function of $\mathrm{pH}$.

\begin{tabular}{clcccccc}
\hline $\mathrm{M}^{2+}$ & $\mathrm{pH}$ & PHBRF-I & PHBRF-II & $\mathrm{M}^{2+}$ & $\mathrm{pH}$ & PHBRF-I & PHBRF-II \\
\hline & 3 & 187.36 & 256.48 & & 3 & 126.35 & 184.7 \\
& 3.5 & 216.75 & 293.45 & & 3.5 & 153.46 & 204.92 \\
& 4 & 256.48 & 315.41 & & 4 & 184.69 & 256.28 \\
$\mathrm{Cu}^{2+}$ & 4.5 & 298.16 & 398.44 & $\mathrm{Cd}^{2+}$ & 4.5 & 217.36 & 298.53 \\
& 5 & 348.33 & 453.37 & & 5 & 241.14 & 321.45 \\
& 5.5 & 398.25 & 502.48 & & 5.5 & 297.36 & 342.57 \\
& 6 & 435.93 & 540.04 & & 6 & 334.02 & 362.73 \\
\hline 3 & 265.26 & 387.53 & & 3 & 116.34 & 236.42 \\
& 3.5 & 289.34 & 418.4 & & 3.5 & 184.75 & 298.15 \\
& 4 & 378.15 & 478.25 & & 4 & 203.43 & 386.24 \\
$\mathrm{Zn}^{2+}$ & 4.5 & 398.44 & 502.48 & $\mathrm{Ni}^{2+}$ & 4.5 & 287.55 & 478.37 \\
& 5 & 468.26 & 566.24 & & 5 & 312.41 & 546.77 \\
& 5.5 & 496.35 & 587.06 & & 5.5 & 354.28 & 596.36 \\
& 6 & 530.03 & 750.44 & & 6 & 371.98 & 623.06 \\
\hline & 3 & 84.33 & 166.45 & & 3 & 67.46 & 206.7 \\
& 3.5 & 124.45 & 215.63 & & 3.5 & 134.55 & 287.59 \\
& 4 & 145.78 & 262.47 & & 4 & 197.36 & 358.27 \\
$\mathrm{~Pb}^{2+}$ & 4.5 & 165.28 & 334.67 & $\mathrm{Co}^{2+}$ & 4.5 & 214.76 & 464.87 \\
& 5 & 185.54 & 445.09 & & 5 & 286.35 & 512.64 \\
& 5.5 & 228.44 & 548.26 & & 5.5 & 305.47 & 668.73 \\
6 & 241.53 & 551.65 & & 6 & 399.54 & 784.44 \\
\hline
\end{tabular}

$\mathrm{Mt}\left(\mathrm{NO}_{3}\right)=0.1 \mathrm{M}, 2 \mathrm{~mL}$, Electrolyte $=\mathrm{NaNO}_{3} 1 \mathrm{M} 25 \mathrm{~mL}$, Equilibrium state $=24 \mathrm{~h}$, Wt. of resin $=25 \mathrm{mg}$, Temp $=$ Room temp.

\section{Conclusions}

The elemental analysis, UV-Vis spectra, IR spectra and ion exchange properties support to the tentative structure of PHBRF resins shown above. The study of ion exchange data in general, show the order PHBRF-I < PHBRF-II that conclude the fact that the chelating ion exchange properties depend upon the number of active site (No. of - $\mathrm{OH}$ group) present on polymeric matrix. The rate of metal ion uptake found to increase in order PHBRF-I < PHBRF-II. The electrolyte $\mathrm{Na}_{2} \mathrm{SO}_{3}$ and $\mathrm{Na}_{2} \mathrm{SO}_{4}$ are not suitable for ion exchange as compared to $\mathrm{NaNO}_{3}$ and $\mathrm{NaCl}$. The resins PHBRF-I can be used to separate $\mathrm{Co}^{2+}-\mathrm{Zn}^{2+}$ and $\mathrm{Zn}^{2+}-\mathrm{Pb}^{2+}$ at $\mathrm{pH} 3.0$ and at $\mathrm{pH} 6.0$ respectively. Similarly PHBRF-II show high selectivity for $\mathrm{Zn}^{2+}$ and $\mathrm{Co}^{2+}$ at $\mathrm{pH} 3.0$ and 6.0 respectively. However the terpolymeric resins show high selectivity for $\mathrm{Cu}^{2+}, \mathrm{Zn}^{2+}$ and $\mathrm{Co}^{2+}$ as compared to $\mathrm{Ni}^{2+}, \mathrm{Pb}^{2+}$ and $\mathrm{Cd}^{2+}$.

\section{Acknowledgement}

One of the authors is thankful to UGC Delhi for granting fellowship under FIP and Principal, Arts, commerce and Science College, Arvi Dist- Wardha.. We are also grateful to Director and R.H. Limsey, Head, Dept. of Chemistry, Institute of Science, Nagpur for providing available facilities at the centre and to Dr. R. S. Bhavsar and Dr. R. B. Kharat for continuous encouragement. We are thankful to Director \& Avtar Singh, SAIF, Punjab University, for analyzing the samples.

\section{References}

1. Kuhin R, Ion exchange resin, $3^{\text {rd }}$ Edn., Whiley, New York, 1958. 
2. Verma J K and Verma A G, Asian J Chem., 2004, 16, 1653.

3. Samal U K, Nayak P L and Lenka S, J Appl Polym Sci., 1993, 47, 1315.

4. Gurunule W B, Rahangdale P K, Paliwal L J and Kharat R B, React Funct Polym., 2003, 55, 255.

5. Pal T K and Kharat R B, J Indian Chem Soc., 1989, 66, 286.

6. Pal T K and Kharat R B, Indian J Chem., 1989, 28A, 55.

7. Mondal B C and Das A. K, J Indian Chem Soc., 2004, 81, 95.

8. Bawankar S V, Paliwal L J and Kharat R B, Asian J Chem., 1999, 11, 1185.

9. Manavalan R and Patel M M, J Indian Chem Soc., 1984, 61, 490.

10. Banarjee D, Mondal B C and Das A K, J Indian Chem Soc., 2004, 81, 53.

11. Shah B A, Shah A V and Shah P M, Iran Polym J., 2006, 15, 809.

12. Shah B A, Shah AV, Bhandari B N and Bhatt R R, J Iran Chem Soc., 2008, 5, 252.

13. Hiwase V V, Kalambe A B, Umare S S and Khedkar K M, Acta Ciencia Indica Chem., 2007, 33C, 615.

14. Morrison R T and Boyd R N, Org Chem., $6^{\text {th }}$ Edn, Prentice Hall India Pvt Ltd, 2004.

15. Patel J R and Patel M N, High Perfom Polym., 1994, 6, 201.

16. Silverstein R M and Webster F X, Spectrometric Identification of organic compounds $6^{\text {th }}$ Ed., John Willey, New York, 1998. 


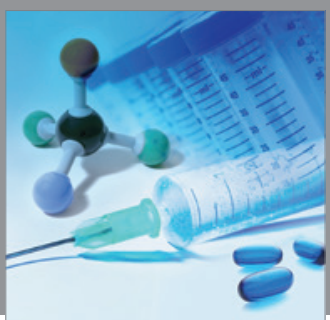

International Journal of

Medicinal Chemistry

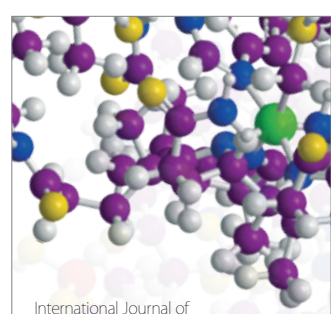

Carbohydrate Chemistry

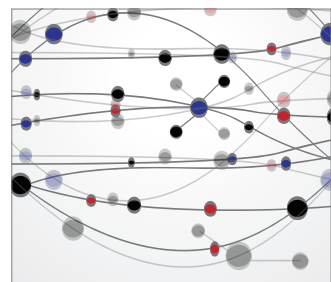

The Scientific World Journal
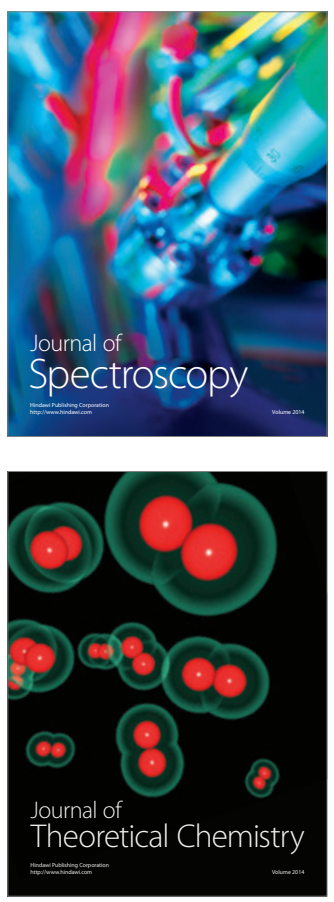
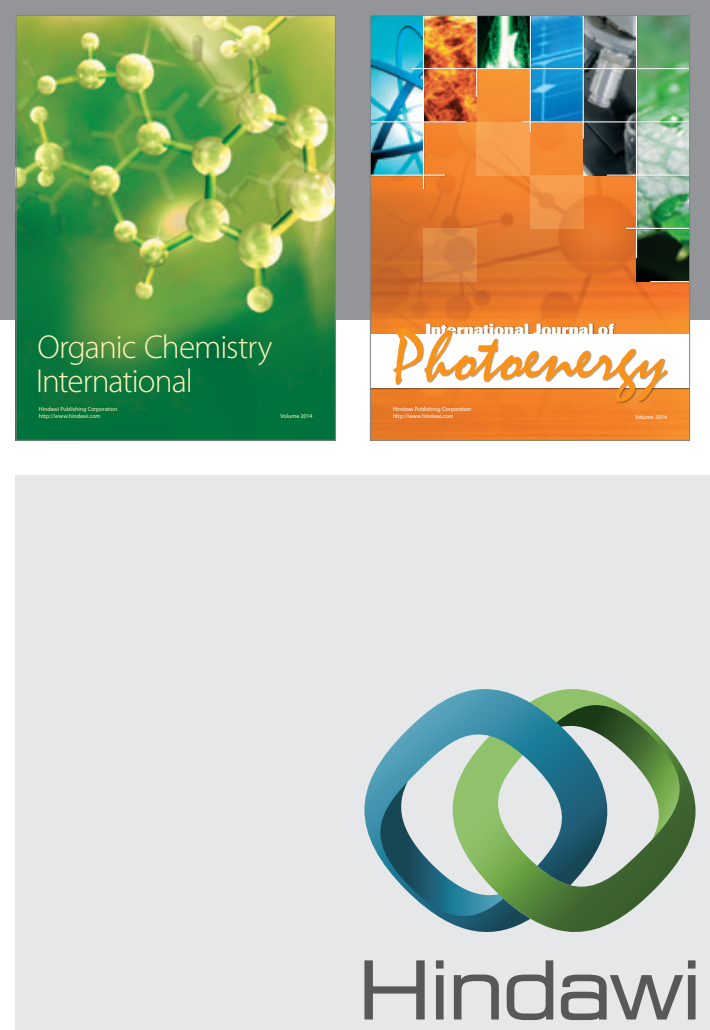

Submit your manuscripts at

http://www.hindawi.com
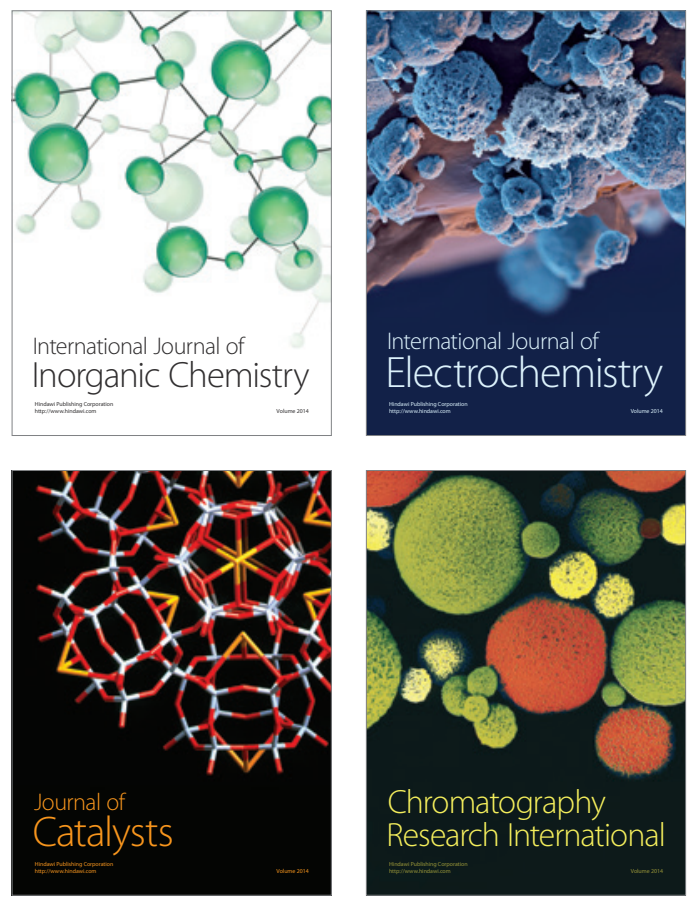
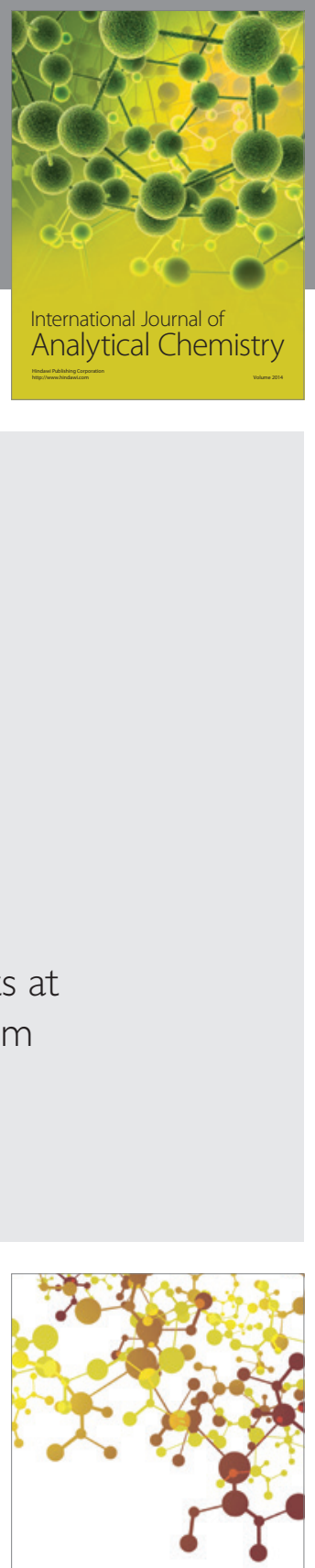

Journal of

Applied Chemistry
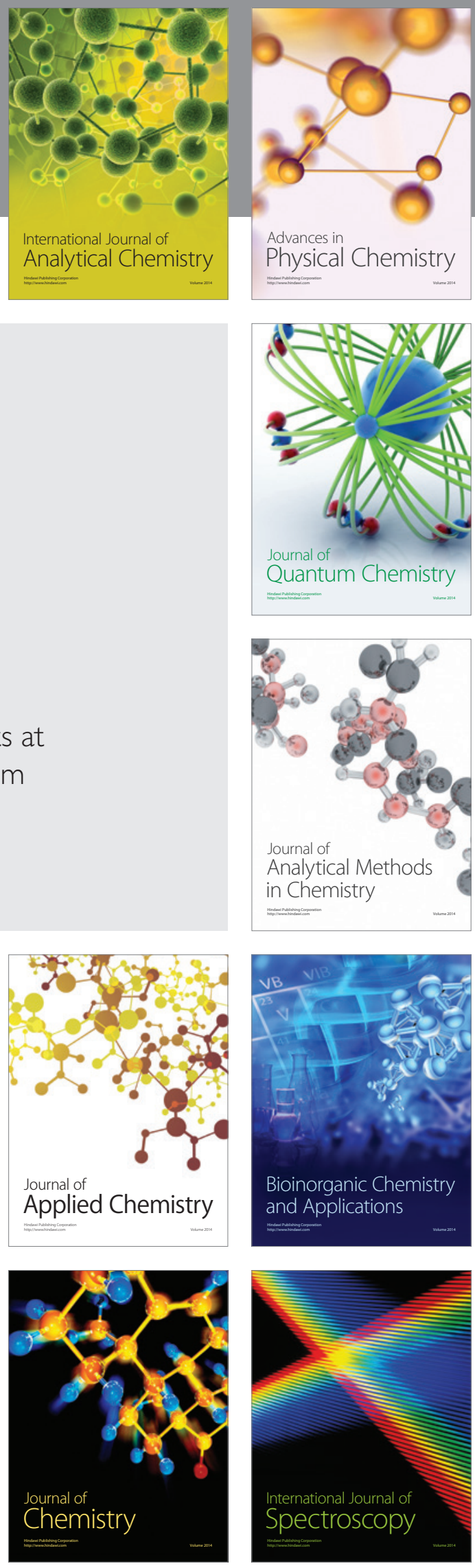